\title{
Performance of New Sugarcane Varieties in the Lajas Valley Area ${ }^{1}$
}

\author{
G. Tamírez-Oliveras, M. Pérez-Zapata, and C. González-Molina²
}

ABSTRACT

Three sites were selected in the Lajas Valley area of Puerto Rico for the performance evaluation of 50 new sugarcane varieties. A plant crop (fall planting) and two ratoon crops were harvested at each site.

At the Santa Rita farm, located at the eastern part of the Lajas Valley, the outstanding varieties were: PR 61-902, CP 52-43, and PR 1140. PR 1140 and CP 52-43 are very promising due to their erect growth and good juice quality.

At Cerrete farm, situated in the saline and poorly drained soils of the central section of the Valley, the outstanding variety was NCo 310 , which outyielded commercial varieties PR 980, PR 1013, and B 49-119 in tonnage and sucrose content.

At the Lajas Substation, in the western end of the Valley, there were no differences in varietal performance for 18 of the 30 varieties tested. PR 61902 had the best overall yield throughout the Valley.

\section{INTRODUCTION}

The Lajas Valley, located in the southwestern part of Puerto Rico, comprises 102,609 acres, of which 20,000 can be irrigated. Of this total, 16,000 acres were planted to sugarcane in 1975 , with a mean yield of 24 tons of cane and 2.05 tons of sugar per acre (2).

The entire area depends on supplementary irrigation due to lack of sufficient rainfall (30 to $40 \mathrm{in} / \mathrm{yr}$ ), mainly during the months of August through November. Irrigation is supplied by the Puerto Rico Water Resources Authority, a government agency, at a cost of $\$ 6.00$ per acrefoot. Farmers are provided with 3 acre-feet of water/acre/year (4).

The principal varieties of sugarcane grown in the Lajas Valley are: PR 980, PR 1013, PR 1028, and B 49-119. PR 980 is an intermediate maturing cane, with low juice quality, particularly in poorly-drained soils. PR 1028 is an early-maturing variety with high sucrose. PR 1013, which adapts to dry soils, is an intermediate-maturing and high-sucrose variety. B 49-119 is an early-maturing, low-sucrose variety well adapted to heavy, saline soils.

Most of the cane in the Valley is harvested by soldier-type machines, which require erect-growing varieties for maximum efficiency. Some of the varieties grown vary from semi-erect to recumbent, and much damaged cane is left in the field after harvesting. When cane is so

${ }^{1}$ Manuscript submitted to Editorial Board April 4, 1977.

${ }^{2}$ Research Assistant, Assistant Agronomist, and Plant Breeder, respectively, Agricultural Experiment Station, Mayagüez Campus, University of Puerto Rico, Río Piedras, P.R. 
harvested, there is an increase of extraneous matter that goes to the mill and an attendant decrease in sugar recovery.

The soils of the Valley are heavy clays with very low water infiltration capacity and a high water table (1). This has created problems of soil salinity in some areas in the lower parts of the valley.

The purpose of this paper is to present the results of sugarcane variety trials performed from 1970 to 1974 and to evaluate new and higher sugar-yielding varieties for the Valley, consonant with its needs relative to soil, irrigation, salinity, and drainage problems.

\section{MATERIALS AND METHODS}

Experiments were conducted at the Santa Rita, Cerrete, and Substation farms, corresponding to the Valley's eastern, lower-central, and western sections, respectively.

The prevailing soil at the Santa Rita farm is Cartagena, a member of a fine, mixed, isohyperthermic family of Udic Chromusterts. These soils have very dry grayish brown clay A horizons, and dark grayish brown clay $\mathrm{C}$ horizons that crack when dry (5). ${ }^{3}$

Thirty varieties were tested at the Santa Rita farm employing a $5 \times$ 6 rectangular lattice design with six replications. The experiment was planted on October 31, 1970 (fall planting) and harvested on February 29, 1972. The first ratoon crop was harvested on April 30, 1973 and the second on April 2, 1974.

At the Cerrete farm, the soil is classified as Aguirre, a fine, mixed, isohyperthermic, Udic Pellusterts. These soils have very dark gray fine-textured A horizons and olive-gray to olive-brown fine-textured and very plastic calcareous $\mathrm{C}$ horizons having many slickensides and pressure faces (5). ${ }^{3}$ Twenty-five sugarcane varieties were tested at this site using a $5 \times 5$ balanced lattice design with six replications. The experiment was planted on November 24, 1970 and harvested on March 3, 1972. The first ratoon was harvested on March 30, 1973 and the second on April 18, 1974.

At the Lajas Substation farm, the prevailing soil is Fraternidad, a very fine montmorillonitic isohyperthermic family of Udic Chromusterts. These soils have very dark, grayish-brown fine-textured surface layers, and brown, fine-textured and highly-plastic calcareous $\mathrm{C}$ horizons (5). ${ }^{3}$ Thirty sugarcane varieties were tested using a $5 \times 6$ rectangular lattice design with six replications. The varieties were planted on November 5, 1970 and harvested April 13, 1972. The first ratoon was harvested on April 23, 1973 and the second on April 8, 1974.

At all experimental sites, plots were $22 \times 20 \mathrm{ft}$ with furrows $5.5 \mathrm{ft}$ apart. Standard field management operations employed by the commer-

\footnotetext{
${ }^{3}$ Also, Soil Survey Interim Report, USDA, Soil Conservation Service (in press).
} 
cial cane growers at each location were also applied to each experimental site.

The following varieties were tested in each site:

\begin{tabular}{lll} 
Santa Rita & \multicolumn{1}{c}{ Cerrete } & Lajas Substation \\
PR 980 & PR 980 & PR 980 \\
PR 1013 & PR 1002 & PR 1013 \\
PR 1028 & PR 1013 & PR 1028 \\
PR 1117 & PR 1140 & PR 1048 \\
PR 1140 & PR 1141 & PR 1059 \\
PR 1141 & PR 1152 & PR 1117 \\
PR 1152 & PR 1249 & PR 1140 \\
PR 1175 & PR 61-53 & PR 1141 \\
PR 1191 & PR 61-902 & PR 1148 \\
PR 1238 & PR 62-52 & PR 1152 \\
PR 61-902 & PR 62-258 & PR 1238 \\
PR 62-52 & PR 62-285 & PR 1239 \\
PR 62-258 & PR 62-838 & PR 1240 \\
PR 62-285 & PR 63-227 & PR 1248 \\
PR 62-739 & PR 64-400 & PR 1249 \\
PR 64-15 & PR 64-610 & PR 61-902 \\
PR 64-142 & PR 64-1548 & PR 62-174 \\
PR 64-307 & PR 64-1791 & PR 62-258 \\
PR 64-352 & PR 65-720 & PR 63-227 \\
PR 64-774 & PR 65-870 & PR 64-152 \\
PR 64-795 & B 42-231 & PR 64-307 \\
PR 64-1548 & B 49-119 & PR 64-352 \\
PR 64-1791 & CP 52-43 & PR 64-610 \\
PR 65-625 & UCW 53-69 & PR 64-747 \\
PR 65-843 & NCo 310 & PR 65-720 \\
PR 65-868 & & PR 65-795 \\
PR 65-870 & & PR 65-868 \\
B 49-119 & & PR 65-870 \\
CP 52-43 & & B 49-119 \\
NC0 310 & &
\end{tabular}

Irrigation was used at each site to supplement scanty rainfall. All three experiments were hand-harvested after burning. Complete plot yields were weighed and 10-cane samples of each plot were taken for sugar analysis by the pol-ratio method. Satistical analyses were performed on cane tonnage, rendement, and tons of sugar per acre. A combined analysis of the three crops was made, exclusive of the Cerrete farm, where only plant and first ratoon data were used owing to damage of the pol-ratio samples in the second-ratoon crop.

\section{RESULTS AND DISCUSSION}

EASTERN SECTION (SANTA RITA FARM)

For the poorly-drained, slightly saline soils of the eastern section of the Valley, PR 61-902, CP 52-43, and PR 1140 were the leading varieties 
in tons of sugar per acre, as indicated by the combined analyses of the plant and ratoon crops (table 1). PR 61-902, a new variety, ranked highest among the three crops evaluated, showing high values for both cane tonnage and sucrose-percent-cane. Unfortunately, it has a tendency to lodge when tonnages are high. Poor stooling has also been noted, but in this experiment it did not affect tonnage.

CP 52-43 ranked second in the combined analyses of the three crops, having a ranking of third in the plant crop, fourth in the first ratoon, and fifth in the second ratoon. The overall performance of PR 1140 ranked third for the three crops, but it was not consistent, ranking fourteenth in the plant crop with a fair cane tonnage, third in the first ratoon with outstanding sucrose tonnage, and ninth in the second ratoon due to only fair sucrose values.

PR 1028, one of the standard commercial varieties in this area ranked fourth, but PR 61-902 was significantly superior in yield, producing an additional 0.78 ton of sugar/acre. B-49-119, a commercial variety sometimes used in the area, ranked twenty-seventh.

\section{CENTRAL SECTION (CERRETE FARM)}

The only outstanding variety at the Cerrete farm was NCo 310; in. tons of sugar per acre for the two crops, it was significantly superior to all other varieties (table 2). NCo 310 is an early-flowering, high-sucrose variety, well adapted to the poorly-drained saline soils of the central section of the Valley. The results reported in this paper agree with the performance of this variety previously reported (3). During heavy tonnage years it lodges heavily, but it can be harvested by the cut-andload harvesting machines. Clinging trash and thin stalks make NCo 310 unpopular among some sugarcane farmers who use the soldier-type harvester. Although NCo 310 may be cut early, it also carries over well for late harvesting with little deterioration in sucrose. PR 64-1548, a promising new variety, ranked second, with commercial varieties PR 1013, PR 980, and B 49-119 ranking third, sixth, and fourteenth, respectively (table 2 ).

\section{WESTERN SECTION (SUBSTATION FARM)}

In the Lajas Substation farm, in the western section of the Valley, variety PR 1059 was not significantly better than 17 other varieties out of the 30 evaluated. Uniform water supply, fertile soil, and plentiful rainfall tended to affect all varieties favorably. Although PR 1059 ranked first in the plant crop, it ranked tenth and twelfth in the first and second ratoons, respectively. This variety showed erratic performance, possibly due to ratoon stunting disease, to which this variety is highly susceptible. 
TABLE 1.-Mean yields of sugarcane varieties at Santa Rita farm in Guánica

\begin{tabular}{|c|c|c|c|c|c|}
\hline Rank & Variety & Sucrose & Cane & Sugar & Fiber \\
\hline & & $\%$ & Tons & Tons & $\%$ \\
\hline \multicolumn{6}{|c|}{ A. Plant Cane Crop 1972} \\
\hline 1 & PR 61-902 & 12.32 & 59.4 & $7.29 \mathrm{a}^{1}$ & 14.72 \\
\hline 2 & PR 64-15 & 12.73 & 53.2 & $6.70 \mathrm{ab}$ & 14.53 \\
\hline 3 & CP $52-43$ & 12.67 & 52.8 & $6.67 \mathrm{ab}$ & 14.84 \\
\hline 4 & PR $65-870$ & 10.21 & 62.1 & $6.32 \mathrm{abc}$ & 16.72 \\
\hline 5 & PR 1028 & 12.50 & 49.0 & $6.03 \mathrm{abc}$ & 16.50 \\
\hline 6 & PR 62-258 & 12.72 & 47.2 & $5.96 \mathrm{bc}$ & 16.85 \\
\hline 7 & PR $62-52$ & 14.63 & 40.0 & $5.95 \mathrm{bc}$ & 14.59 \\
\hline 8 & PR 1117 & 11.79 & 49.5 & $5.86 \mathrm{bc}$ & 16.45 \\
\hline 9 & NCo 310 & 10.65 & 54.6 & $5.74 \mathrm{bc}$ & 14.85 \\
\hline 10 & PR 1141 & 12.74 & 43.9 & $5.63 \mathrm{bc}$ & 13.84 \\
\hline 16 & PR 980 & 11.07 & 45.1 & $5.03 \mathrm{c}$ & 16.17 \\
\hline \multicolumn{6}{|c|}{ B. First ratoon crop 1973} \\
\hline 1 & PR 61-902 & 11.86 & 40.34 & 4.82 & 16.35 \\
\hline 2 & PR 64-352 & 13.47 & 31.86 & 4.58 & 14.83 \\
\hline 3 & PR 1140 & 14.01 & 30.85 & 4.53 & 16.09 \\
\hline 4 & CP $52-43$ & 11.39 & 37.95 & 4.42 & 17.90 \\
\hline 5 & PR 1028 & 12.68 & 34.44 & 4.39 & 18.72 \\
\hline 6 & PR 62-285 & 10.34 & 38.59 & 4.27 & 17.74 \\
\hline 7 & PR 64-142 & 12.97 & 31.90 & 4.24 & 15.31 \\
\hline 8 & NCo 310 & 10.32 & 42.01 & 4.22 & 16.98 \\
\hline 9 & PR $62-739$ & 10.62 & 39.49 & 4.17 & 16.52 \\
\hline 10 & PR 1141 & 11.83 & 32.69 & 3.85 & 15.94 \\
\hline 18 & PR 980 & 9.36 & 36.58 & 3.54 & 17.20 \\
\hline \multicolumn{6}{|c|}{ C. Second ratoon crop 1974} \\
\hline 1 & PR 61-902 & 12.50 & 27.84 & $3.51 \mathrm{a}$ & 17.03 \\
\hline 2 & NCo 310 & 10.74 & 31.32 & $3.36 \mathrm{ab}$ & 17.47 \\
\hline 3 & PR 62-739 & 10.67 & 31.02 & $3.26 \mathrm{ab}$ & 16.72 \\
\hline 4 & PR 64-352 & 13.01 & 25.11 & $3.26 \mathrm{ab}$ & 14.80 \\
\hline 5 & CP $52-43$ & 11.61 & 28.40 & $3.23 \mathrm{ab}$ & 17.15 \\
\hline 6 & PR 1141 & 12.31 & 25.58 & $3.15 \mathrm{ab}$ & 15.35 \\
\hline 7 & PR 1013 & 11.59 & 27.02 & $3.13 \mathrm{ab}$ & 15.48 \\
\hline 8 & PR 1152 & 10.80 & 28.53 & $3.09 \mathrm{ab}$ & 15.53 \\
\hline 9 & PR 1140 & 10.72 & 28.39 & $3.06 \mathrm{ab}$ & 16.74 \\
\hline 10 & PR $65-625$ & 10.37 & 28.97 & $3.01 \mathrm{ab}$ & 17.12 \\
\hline 11 & PR 1028 & 10.95 & 26.82 & $2.96 \mathrm{ab}$ & 17.44 \\
\hline 18 & PR 980 & 9.84 & 28.99 & $2.76 \mathrm{~b}$ & 17.52 \\
\hline \multicolumn{6}{|c|}{ D. Combined analysis ${ }^{2}$} \\
\hline 1 & PR 61-902 & 12.28 & 42.51 & $5.25 \mathrm{a}$ & 16.02 \\
\hline 2 & CP $52-43$ & 11.63 & 39.72 & $4.66 \mathrm{ab}$ & 16.48 \\
\hline 3 & PR 1140 & 12.85 & 34.63 & $4.53 \mathrm{ab}$ & 16.38 \\
\hline 4 & PR 1028 & 12.07 & 36.75 & $4.47 \mathrm{~b}$ & 17.43 \\
\hline 5 & NCo 310 & 10.60 & 42.65 & $4.44 \mathrm{~b}$ & 16.42 \\
\hline 6 & PR 65-870 & 9.60 & 44.62 & $4.37 \mathrm{~b}$ & 18.18 \\
\hline 7 & PR 64-15 & 12.02 & 35.95 & $4.24 \mathrm{~b}$ & 14.85 \\
\hline 8 & PR 64-352 & 12.44 & 34.09 & $4.24 \mathrm{~b}$ & 14.62 \\
\hline 9 & PR 1141 & 12.29 & 34.06 & $4.22 \mathrm{~b}$ & 15.03 \\
\hline 10 & PR $62-258$ & 11.68 & 35.13 & $4.21 \mathrm{~b}$ & 18.22 \\
\hline 18 & PR 980 & 10.17 & 36.87 & $3.82 \mathrm{~b}$ & 16.95 \\
\hline
\end{tabular}

${ }^{1}$ Values followed by one or more letters in common do not differ significantly at the .05 level.

${ }^{2}$ Pooled data from plant cane and first ratoon crops only. 
Among the 18 leading varieties in the Substation experiment, PR 64747 , an erect, high-sucrose variety, compared favorably with the commercial varieties in stooling habit. PR 1152, an erect, high-sucrose variety, is well adapted to merchanization and is a potential substitute for commercial varieties grown in the non-saline, well-drained soils of the Valley.

TABLE 2. - Mean yields of sugarcane varieties at Cerrete farm in Lajas

\begin{tabular}{|c|c|c|c|c|c|}
\hline Rank & Variety & Sucrose & Cane & Sugar & Fiber \\
\hline & & $\%$ & Tons & Tons & $\%$ \\
\hline \multicolumn{6}{|c|}{ A. Plant cane crop 1972} \\
\hline 1 & NCo 310 & 12.68 & 39.7 & $4.94 \mathrm{a}^{1}$ & 14.66 \\
\hline 2 & PR 1013 & 11.52 & 32.8 & $3.78 \mathrm{~b}$ & 13.37 \\
\hline 3 & PR 980 & 11.93 & 30.7 & $3.64 \mathrm{~b}$ & 14.67 \\
\hline 4 & PR $64-400$ & 10.53 & 33.3 & $3.50 \mathrm{~b}$ & 15.67 \\
\hline 5 & B 42-231 & 9.34 & 36.4 & $3.41 \mathrm{~b}$ & 15.81 \\
\hline 6 & PR 61-902 & 11.08 & 30.8 & $3.41 \mathrm{~b}$ & 15.22 \\
\hline 7 & UCW 53-69 & 9.41 & 36.1 & $3.41 \mathrm{~b}$ & 16.95 \\
\hline 8 & PR 62-258 & 12.35 & 27.9 & $3.4 .0 \mathrm{~b}$ & 17.95 \\
\hline 9 & PR 64-1548 & 11.73 & 29.0 & $3.38 \mathrm{~b}$ & 16.31 \\
\hline 10 & PR 64-1791 & 9.37 & 34.8 & $3.31 \mathrm{~b}$ & 16.87 \\
\hline 11 & B 49-119 & 9.77 & 33.3 & $3.27 \mathrm{~b}$ & 15.09 \\
\hline \multicolumn{6}{|c|}{ B. First ratoon crop 1973} \\
\hline 1 & NCo 310 & 9.33 & 28.66 & $2.73 \mathrm{a}$ & 17.99 \\
\hline 2 & PR 64-1548 & 9.64 & 21.52 & $2.08 \mathrm{~b}$ & 17.59 \\
\hline 3 & B $42-231$ & 7.95 & 24.83 & $2.00 \mathrm{~b}$ & 20.64 \\
\hline 4 & UCW 53-69 & 7.11 & 24.93 & $1.77 \mathrm{bc}$ & 19.91 \\
\hline 5 & PR 62-285 & 7.86 & 20.49 & $1.69 \mathrm{bc}$ & 19.31 \\
\hline 6 & PR 1013 & 7.25 & 22.28 & $1.68 \mathrm{bc}$ & 18.87 \\
\hline 7 & CP 52-43 & 8.97 & 18.02 & $1.60 \mathrm{bc}$ & 19.83 \\
\hline 8 & PR 1002 & 8.31 & 19.19 & $1.59 \mathrm{bc}$ & 18.54 \\
\hline 9 & PR 62-258 & 9.67 & 16.02 & $1.55 \mathrm{bc}$ & 19.78 \\
\hline 10 & PR 62-52 & 9.22 & 15.95 & $1.52 \mathrm{bc}$ & 17.64 \\
\hline 19 & B 49-119 & 8.01 & 16.91 & $1.36 \mathrm{c}$ & 18.28 \\
\hline 20 & PR 980 & 7.18 & 18.23 & $1.34 \mathrm{c}$ & 18.82 \\
\hline \multicolumn{6}{|c|}{ C. Combined analysis ${ }^{2}$} \\
\hline 1 & NCo 310 & 10.99 & 34.20 & $3.84 \mathrm{a}$ & 16.33 \\
\hline 2 & PR 64-1548 & 10.68 & 25.25 & $2.73 \mathrm{~b}$ & 16.95 \\
\hline 3 & PR 1013 & 9.38 & 27.56 & $2.73 \mathrm{~b}$ & 16.12 \\
\hline 4 & B $42-231$ & 8.64 & 30.59 & $2.72 \mathrm{~b}$ & 18.23 \\
\hline 5 & UCW 53-69 & 8.25 & 30.50 & $2.59 \mathrm{~b}$ & 18.42 \\
\hline 6 & PR 980 & 9.55 & 24.47 & $2.50 \mathrm{~b}$ & 16.75 \\
\hline 7 & PR $64-400$ & 9.47 & 25.27 & $2.50 \mathrm{~b}$ & 17.32 \\
\hline 8 & PR 62-258 & 11.00 & 21.97 & $2.48 \mathrm{~b}$ & 18.87 \\
\hline 9 & PR 61-902 & 10.84 & 22.11 & $2.47 \mathrm{~b}$ & 16.24 \\
\hline 10 & PR $62-285$ & 9.42 & 23.37 & $2.42 \mathrm{~b}$ & 17.53 \\
\hline 14 & B $49-119$ & 8.88 & 25.08 & $2.31 \mathrm{~b}$ & 16.69 \\
\hline
\end{tabular}

${ }^{1}$ Values followed by one or more letters in common do not differ significantly at the .05 level.

2 Pooled data from plant cane and first ratoon crops only. 
TABLE 3.-Mean yields and relative values of sugarcane varieties at the Experimental

Substation farm in Lajas

\begin{tabular}{|c|c|c|c|c|c|}
\hline Rank & Variety & Sucrose & Cane & Sugar & Fiber \\
\hline & $\%$ & Tons & Tons & $\%$ & $\%$ \\
\hline \multicolumn{6}{|c|}{ A. Plant Cane crop 1972} \\
\hline 1 & PR 1059 & 13.93 & 54.3 & 7.61 & 14.03 \\
\hline 2 & PR 1141 & 12.90 & 54.2 & 7.00 & 12.67 \\
\hline 3 & PR 64-747 & 14.47 & 47.9 & 6.92 & 13.39 \\
\hline 4 & PR 64-352 & 13.28 & 51.2 & 6.82 & 13.96 \\
\hline 5 & PR 1239 & 12.88 & 51.2 & 6.56 & 14.11 \\
\hline 6 & PR 1249 & 12.57 & 51.3 & 6.53 & 14.38 \\
\hline 7 & PR 61-902 & 12.17 & 53.7 & 6.51 & 14.94 \\
\hline 8 & PR 1238 & 13.03 & 50.2 & 6.51 & 14.07 \\
\hline 9 & PR 64-610 & 14.70 & 43.7 & 6.41 & 13.68 \\
\hline 10 & PR 980 & 13.67 & 46.6 & 6.40 & 14.85 \\
\hline 12 & PR 1152 & 13.47 & 46.6 & 6.35 & 14.13 \\
\hline 14 & PR $62-258$ & 11.79 & 53.1 & 6.28 & 16.25 \\
\hline \multicolumn{6}{|c|}{ B. First ratoon crop 1973} \\
\hline 1 & PR 62-258 & 12.51 & 39.27 & 4.90 & 17.98 \\
\hline 2 & PR 1140 & 13.27 & 36.04 & 4.82 & 15.79 \\
\hline 3 & B 49-119 & 12.79 & 37.30 & 4.71 & 17.15 \\
\hline 4 & PR 61-902 & 13.50 & 33.71 & 4.55 & 16.48 \\
\hline 5 & PR 62-174 & 13.32 & 33.62 & 4.47 & 15.68 \\
\hline 6 & PR $65-868$ & 11.41 & 37.00 & 4.25 & 16.66 \\
\hline 7 & PR 64-352 & 13.71 & 30.43 & 4.20 & 15.30 \\
\hline 8 & PR 64-747 & 13.38 & 31.41 & 4.20 & 14.96 \\
\hline 9 & PR 1028 & 12.73 & 32.83 & 4.18 & 18.41 \\
\hline 10 & PR 1059 & 12.25 & 34.34 & 4.16 & 15.57 \\
\hline 11 & PR 1152 & 11.91 & 35.08 & 4.16 & 16.50 \\
\hline 12 & PR 64-610 & 14.53 & 28.21 & 4.09 & 15.20 \\
\hline \multicolumn{6}{|c|}{ C. Second ratoon crop 1974} \\
\hline 1 & PR 1152 & 11.34 & 35.22 & 4.01 & 16.16 \\
\hline 2 & PR 1048 & 11.11 & 35.27 & 3.92 & 15.86 \\
\hline 3 & PR 1140 & 11.18 & 34.98 & 3.90 & 17.34 \\
\hline 4 & PR 64-747 & 12.97 & 30.05 & 3.88 & 15.44 \\
\hline 5 & PR 64-610 & 12.45 & 29.91 & 3.74 & 14.58 \\
\hline 6 & PR 1249 & 11.26 & 32.87 & 3.72 & 15.74 \\
\hline 7 & PR 64-352 & 12.10 & 30.34 & 3.71 & 15.34 \\
\hline 8 & PR 1028 & 11.64 & 31.67 & 3.66 & 17.99 \\
\hline 9 & PR 1013 & 10.98 & 32.85 & 3.66 & 15.32 \\
\hline 10 & PR 65-868 & 10.58 & 34.24 & 3.63 & 17.82 \\
\hline 11 & PR 980 & 9.92 & 36.19 & 3.60 & 17.66 \\
\hline 12 & PR 1059 & 11.46 & 30.77 & 3.53 & 16.76 \\
\hline 20 & PR 62-258 & 9.07 & 35.02 & 3.17 & 19.76 \\
\hline \multicolumn{6}{|c|}{ D. Combined analysis } \\
\hline 1 & PR 1059 & 12.54 & 39.79 & 5.10 & 15.44 \\
\hline 2 & PR 64-747 & 13.60 & 36.46 & 5.00 & 14.59 \\
\hline 3 & PR 64-352 & 13.03 & 37.33 & 4.91 & 14.86 \\
\hline 4 & PR 1152 & 12.24 & 38.96 & 4.84 & 15.59 \\
\hline 5 & PR 61-902 & 11.94 & 39.97 & 4.79 & 16.73 \\
\hline 6 & PR 62-258 & 11.12 & 42.46 & 4.78 & 17.99 \\
\hline 7 & PR 64-610 & 13.89 & 33.95 & 4.75 & 14.47 \\
\hline 8 & PR 1249 & 11.92 & 39.27 & 4.75 & 15.36 \\
\hline 9 & PR 1140 & 12.19 & 38.20 & 4.63 & 15.97 \\
\hline 10 & PR 1141 & 12.41 & 36.95 & 4.62 & 14.29 \\
\hline 12 & PR 980 & 11.57 & 38.76 & 4.58 & 16.23 \\
\hline
\end{tabular}


The production of sugar per acre was not uniform for all three sections of the Valley. The eastern (Santa Rita farm, table 1) and western (Substation farm, table 3) sections, gave similar production. The lower central section of the Valley (Cerrete farm, table 2) had a lower sugar production, amounting to about half that obtained in the other two areas. The lower production was due mostly to the poorer drainage and higher salinity of these soils.

Since many of the varieties were not repeated in all three sites, it is difficult to make an overall comparison of all varieties. PR 61-902 appears to be capable of giving good sugar tonnage for the whole of the Valley. It is a thick-stalked, high-sucrose variety with good tonnage. It tends to lodge when tonnages are high, but it can be harvested by the cut-and-load harvester. NCo 310 is better than PR 61-902 only for the low central section of the Valley, which has drainage and salinity problems. PR 980, the commercial variety for the major part of the Valley, was surpassed by PR 61-902 in the eastern section, and by NCo 310 in the middle section, but was superior in the western section.

The variation in fiber-percent-cane was greater between varieties in a given experiment than between the three experimental sites (tables 1-3). PR 61-902 averaged 16.33 in fiber percentage as compared to 16.64 for $\mathrm{PR}$ 980. These values were in the intermediate range for fiber percentage of cane.

\section{RESUMEN}

En el Valle de Lajas se seleccionaron tres sitios representativos de los tres suelos más importantes sembrados de caña de azúcar. Estos suelos son: Fraternidad, Aguirre y Cartagena. Todos pertenecen a la misma asociación de suelos, de aluvión, calcáreos, moderadamente bien desaguados o de desagüe defectuoso y de topografía casi llana 0 inclinada. Los experimentos fueron ubicados en las fincas Santa Rita, Cerrete y Subestación Experimental de Lajas, al este, centro y oeste al Valle.

Una siembra de gran cultura y dos retoños se cosecharon en cada uno de los tres sitios. Se recopiló y se analizó estadísticamente información sobre rendimiento, toneladas de caña y toneladas de azúcar por acre de todas las variedades.

En la finca Santa Rita fueron superiores las variedades: PR 61-902, CP 52-43 y PR 1140. La mejor fue la PR 61-902, con altos rendimientos en porcentaje de sacarosa y tonelaje de caña. La variedad CP 52-43 ocupó el segundo lugar en el análisis combinado de las tres cosechas. No hubo diferencias significativas entre las tres variedades, las que parecen ser aptas para sembrarse comercialmente en el área. La variedad PR 61902 amerita se siga observando para determinar su adaptabilidad a nuevos métodos de mecanización.

La variedad NCo 310 fue superior en la finca Cerrete. La PR 64-1548, una nueva variedad prometedora, ocupó el segundo lugar, sobrepasando a las variedades comerciales del área, tales como PR 980 y B 49-119.

La PR 1059, aunque fue la mejor, no fue significativamente mejor que las otras 17 variedades. Esta variedad es de comportamiento errático en las pruebas de campo, tal vez a causa de su susceptiblidad al enanismo. En las primeras 18 variedades se destaca la PR 64-747 por ser erguida y de jugos ricos en sacarosa. La variedad PR 1152 es también erguida, rica en sacarosa y una potencial sustituta de las variedades comerciales en suelos que no sean salinos y que desagüen bien.

\section{LITERATURE CITED}

1. Bonnet, J. A., and Tirado-Sulsona, P., 1950, Soil Studies in Lajas Valley, Agric. Exp. Stn. Univ. P.R., Bull. 86. 
2. Departamento de Agricultura de los EEUU, Junio 1975, Servicio de Estabilización y Conservación Agrícola, Informe de Molienda y Producción de Azúcar.

3. González, C. L., Pérez-Zapata, M., and Ramírez-Oliveras, G., 1977, Performance of Commerical Sugarcane Varieties in the Aguirre Clay Soil of the Lajas Valley, J. Agric. Univ. P.R. 61 (2): 126-36.

4. Reyes García, R., 1971, Public Irrigation Systems in Puerto Rico, J. Irrigation and Drainage Div., A.S.C.E. 97.

5. Soil Survey Staff, 1965, Soil Survey Lajas Valley Area, Puerto Rico, USDA, Soil Conservation Service, In cooperation with the Univ. of P.R., Series 1961, No. 23. 